\title{
VISOKOŠOLSKO IZOBRAŽEVANJE ODRASLIH V SLOVENIJI S STRATEGIJO ALI BREZ NJE?
} dr. Zoran Jelenc vodja raziskovalnega središča na Andragoškem centru Slovenije

\section{Oblikovanje koncepcije in strategije visokošolskega izobraževanja odraslin}

\begin{abstract}
$\mathrm{N}$ aš znani pedagog Vlado Schmidt, sicer tudi avtor Visokošolske didaktike (1972), je že pred leti duhovito izrazil svoje videnje kakovosti izobraževanja odraslih na visokošolski ravni ali »izrednega študija ", ko je zapisal: »Izredni študij se imenuje sizredni najbrž zato, ker je res izredno, če študent $\mathrm{v}$ takih okoliščinah sploh napreduje «. ${ }^{1}$ Nedvomno si lahko misel razlagamo tudi tako, da je to področje študija povsem ali pa precej neurejeno, kar bi lahko tudi pomenilo, da bodisi ne poteka po nekem ustrezno razvitem konceptu ali strategiji bodisi da takšnega koncepta ali strategije sploh ni, kar tudi pomeni, da ni ustrezne politike, ki bi usmerjala dejavnost na tem področju.
\end{abstract}

Od tedaj je sicer poteklo četrt stoletja in morda se je v tem času le kaj izboljšala kakovost izobraževanja odraslih na visokošolski stopnji; če ne zaradi drugega, vsaj zato, ker so se medtem razvile materialne in tehnične možnosti, ker je izobraževanje odraslih na splošno napredovalo itn. A prav tako, kot tedaj, je nemara tudi zdaj utemeljeno vprašanje: ali imamo sploh izdelano koncepcijo in strategijo na tem področju, ali ne poteka to izobraževanje brez ustrezne politike in ustrezne sistemske urejenosti.

Ker govorimo o izobraževanju odraslih na visokošolski ravni, moramo s koncepcijo in strategijo zajeti obe specifični področji izobraževanja, torej izobraževanje odraslih in visokošolsko izobraževanje. Strategija, ki ne bi upoštevala značilnosti in posebnosti obeh področij ter ki ne bi obeh specifičnih koncepcij in strategij združila $\mathrm{v}$ skupno koncepcijo in strategijo, bi bila pomanjkljiva.
V Sloveniji zadnjih deset let intenzivno in temeljito raziskujemo ter razvijamo koncepcijo in strategijo izobraževanja odraslih. $\mathrm{V}$ projekt smo zajeli tudi visokošolsko izobraževanje odraslih. ${ }^{2}$ Glede na svoj naslov - Izobraževanje odraslih kot dejavnik razvoja Slovenije - je projekt prednostno naravnan $\mathrm{k}$ preučevanju izobraževanja odraslih, visokošolsko izobraževanje je pri tem zajeto le kot področje, na katerem poteka izobraževanje odraslih, tako kot druge ravni in področja izobraževanja, kot so osnovno in srednje (splošno in strokovno), poklicno (formalno in neformalno) ter splošno neformalno. Raziskovanje je že končano, v kratkem bo objavljena tudi njegova zadnja faza - sintezni prikaz koncepije in strategije izobraževanja odraslih.

Celotno visokošolsko izobraževanje je bilo v tem času konceptualno temeljiteje obravnavano predvsem v zvezi s pripravo zakona o visokem šolstvu in nove "šolske zakonodaje « in je bilo, tako kot druga področja in ravni izobraževanja - med temi tudi izobraževanje odraslih -, objavljeno v Beli knjigi o vzgoji in izobraževanju v Sloveniji. ${ }^{3}$ Pri tem lahko ugotovimo, da se prispevek o visokošolskem izobraževanju ${ }^{4} \mathrm{z}$ izobraževanjem odraslih skoraj ne ukvarja, saj ga le tu pa tam mimogrede omenja: ni ga med »temeljnimi elementi urejevanja in stabiliziranja sistema " ter med načeli spreminjanja visokega šolstva (n. d.: 264-265); slutimo pa ga lahko pri ciljih, pri katerih se navaja dostop do visokega šolstva »tako za redni študij kot po drugih študijskih poteh « (n. d.: 267); mimogrede - le v eni točki - je omenjeno tudi pri opisovanju poglavitnih rešitev v Zakonu o visokem šolstvu, pri navajanju vrst študijskih programov, kjer je 
zapisano, da "poteka izvajanje študijskih programov v obliki rednega, če njihova narava to dopušča, pa tudi izrednega študija " (n. d.: 269-270); še največ pa obeta v točki, v kateri govori o prenovi in razvoju študijskih programov, ko pravi, da bo odpravljena togost pri izvajanju študijskih programov ob zagotovitvi ustrezne podpore (čigave?, podčrtal Z. J. in op. Z. J.) "lahko pomembneje prispevala tudi $\mathrm{k}$ prenovi sizrednega študija in $\mathrm{k}$ posodabljanju znanja že zaposlenih visokošolskih diplomantov in diplomantk « (n. d.: 278-279); tudi pri prikazih podatkov o udeležbi v študiju in diplomantih namenja gradivo »izrednemu študiju « bolj malo pozornosti, čeprav na enem mestu (n. d.: 281) omenja, da je upadanje »študija ob delu « povzročilo padec skupnega števila diplomantov; tudi med razvojnimi projekti (n. d.: 289) je »izredni študij « uvrščen le v projekt $\mathrm{z}$ imenom »razvoj drugih izobraževalnih poti«. Visokošolskemu izobraževanju odraslih v Beli knjigi pa je namenjena posebna točka $v$ poglavju Razvoj izobraževanja odraslih, ${ }^{5}$ ki to področje seveda prednostno obravnava s stališča strategije razvoja celotnega izobraževanja odraslih.

Ugotovitev dokaj značilno odslikava odnos, kakršnega imajo oblikovalci splošne in celovite politike izobraževanja do izobraževanja

Oblikovanje strategije visokošlskega izobraževanja odraslih je prepušéeno tistın, ki se ukvarjajo z izohraževanjen odraslih (andragogon), oblikovalcem splošne in celovite (3) strategije visokosolskega irobraževanja pa se ne zdi, da bi morali temu področju namenjati posebno pozornost; podrocje torej dobiva svojo strateskico potrditev predvsen pri oblikovalch strategile razvoja izobrazevania odraslih.

odraslih tudi sicer, $v$ tem pa očitno tudi visokošolsko izobraževanje odraslih ni izjema. Posledice so vidne v položaju, v kakršnem je izobraževanje odraslih na visokošolski ravni pri nas. Po ugotovitvah iz že navedene raziskave o visokošolskem izobraževanju odraslih (ACS, 1994) lahko zanesljivo rečemo, da v Sloveniji močno zaostajamo pri razvoju visokošolskega izobraževanja odraslih.

To, od kod prihajajo pobude, se seveda kaže tudi $\mathrm{v}$ našem prikazu strateških razvojnih usmeritev za razvoj visokošolskega izobraževanja odraslih v nadaljevanju tega prispevka.

Temeljne postavke in ukrepi, ki jih predvidevamo $s$ splošno koncepcijo in strategijo za razvoj izobraževanja odraslih v Sloveniji, je mogoče in je po našem mnenju tudi nujno ustrezno aplicirati tudi v visokošolskem izobraževanju odraslih. Strategija opredeljuje te temeljne točke (vse govorijo o izobraževanju odraslih): sistemska uvrstitev, upravljanje, zakonodaja, financiranje, mreža izvajalcev in programov, razvojna infrastruktura, razvoj kadrov; če temu dodamo še prikaz potreb in način ponudbe (oblike in metode), zajamemo vse bistvene prvine koncepcije in strategije, ki določajo delovanje na tem specifičnem področju vzgoje in izobraževanja.

$\mathrm{V}$ našem prispevku bomo namenili pozornost le nekaterim izmed navedenih točk; tistim, s katerimi opozarjamo na nekatera temeljna vprašanja koncepcije in strategije in ki so bolj pomembne za našo razpravo.

\section{SISTEMSKA UMESTITEV}

Če je izobraževanje in učenje dejavnost, ki poteka vse življenje - koncept in strategijo vseživljenjskosti učenja pa v svetu čedalje bolj sprejemajo in uveljavljajo kot vodilno načelo za obravnavanje in urejanje vsega izobraževanja in učenja -, potem sistem vzgoje in izobraževanja sestavljata dve sistemsko enakovred$\mathrm{ni}$ in enakopravni področji: začetno in nadaljevalno izobraževanje. Začetno izobraževanje (angl. initial education) je izobraževanje, ki zajema nepretrgano izobraževanje, od prve vključitve v izobraževanje (vstopa $\mathrm{v}$ šolo) do izstopa iz izobraževanja in prevzema drugih življenjskih ali delovnih funkcij kot prevladujočih $\mathrm{v}$ življenju, ki sledijo izstopu iz izobraževanja; to področje sicer poznamo kot »izobraževanje otrok in mladine «; - nadaljevalno izobraževanje (angl. continuing ali post-initial education) je vse izobraževanje po začetnem izobraževanju; sinonimni izraz za to je »izobraževanje odraslih«. Obe področji se morata za uresničitev načel, koncepcije in strategije vseživljenjskosti učenja ustrezno organizirati, tako da ohranjata svoje specifičnosti in se hkrati dopolnjujeta. Celovito uresničevanje celovite koncepcije in strategije vseživljenjskosti učenja zahteva naslednje temeljne spremembe v vzgoji in izobraževanju:

1. prestrukturiranje vsega zdajšnjega sistema izobraževanja, še posebno formalnega;

2. vključevanje novih subjektov kot nosilcev in izvajalcev izobraževanja; 
3. usposobitev udeležencev izobraževanja, da postanejo aktiven dejavnik svojega lastnega učenja. ${ }^{6}$

Iz zornega kota takšne konceptualne in strateške usmeritve ni upravičeno šteti določeno področje izobraževanja za redno in drugo za izredno ter jih tako poimenovati. Izobraževanje ali študij odraslih na visokošolski stopnji zdaj pri nas uradno - z novim Zakonom o visokem šolstvu ${ }^{7}$ - spet imenujemo »izredno «. To je korak nazaj! Tak izraz ga $\mathrm{v}$ resnici tudi determinira kot izredno, torej ne redno, tudi po njegovem statusu in položaju, ki ga ima $\mathrm{v}$ sistemu; govorimo o izrazu »izredni študij «. Nedvomno ga kot takšnega tudi obravnavamo, to ima negativne organizacijsko-sistemske, materialne in psihološke učinke in ne obsega le prilagoditev organizacije ter časovne razporeditve predavanj, seminarjev in vaj študentom, kot je napisano v zakonu. Pri tem ničesar bistveno ne spremeni načelna zakonska formulacija, da imajo državljani Republike Slovenije "pravico do izobraževanja na visokošolskih zavodih v Republiki Sloveniji pod enakimi pogoji« (7. člen).

\section{UDELEŽENEC IZOBRAŽEVANJA, UČENJA ALI ŠTUDIJA}

Pri opredeljevanju vrste udeleženca izobraževanja ali študija je treba zaradi specifičnosti položaja, vloge ali možnosti v izobraževanju ločiti in tudi različno imenovati udeleženca začetnega ter nadaljevalnega izobraževanja. Če tega ne naredimo, mečemo vse $\mathrm{v}$ isti koš, namesto da bi udeležence obravnavali v skladu z njihovimi posebnimi potrebami, značilnostmi ali možnostmi. $\mathrm{Na}$ visokošolski ravni seveda imenovanje udeleženca $\mathrm{z}$ izrazom »odrasli« ni najbolj posrečeno, ${ }^{8}$ čeprav gre le za strokovni izraz. "Odraslost« udeleženca ali študenta lahko obravnavamo le v skladu z andragoško opredelitvijo udeleženca izobraževanja odraslih: to je oseba, ki se po formalnem in dejanskem prenehanju svojega začetnega izobraževanja (menimo, da se to zgodi najkasneje $s$ pridobitvijo diplome o visoki izobrazbi; podiplomsko izobraževanje tako štejemo že za nadaljevalno izobraževanje) vrača v izobraževanje: ga nadaljuje z vključitvijo v formalni ali neformalni izobraževalni program ali pa ustrezno (z izobraževanjem ali samostojnim učenjem) dopolnjuje svojo po- klicno in strokovno ter tudi splošno izobrazbo.

Takšen študij, izobraževanje ali učenje na ustrezni visokošolski ustanovi ali $\mathrm{v}$ programih, ki jih te organizirajo, so za človeka aktualni 30, 40 in več let, in ne le štiri leta, takoj po končani srednji šoli. Seveda pa za odraslega udeleženca izobraževanje, učenje ali študij niso prednostna dejavnost, ker namenja prednostno ali vsaj enako pozornost tudi delu, družini in vrsti drugih obveznosti, odgovornosti in vlog odraslega človeka, ki seveda vplivajo na njegove možnosti in organiziranost izobraževanja - ga lahko pospešujejo, lahko pa ga tudi motijo in včasih zavirajo.

Spremembe povzroča spremenjeno gledanje na življenjski ciklus; ta ni več preprosto linearen (model: izobraževanje, delo, upokojitev), temveč cikličen (model: izmenjavanje izobraževanja, dela in počitka skozi vso življenjsko dobo) ali mešani (model: izobraževanje, delo in počitek potekajo hkrati).

Čigava skrb bo to v prihodnje, če se nam zdaj $s$ tem problemom še ni treba intenzivno ukvarjati? Kdo bo za to odgovoren, kdo bo pokrival stroške in komu? Samo načelni odgovor, da bo to urejeno po načelih partnerstva, ne bo rešil proZa visokošolski študij se odloča vedno več odraslih. blema. Potrebna bo ustrezna strategija in politika, ki se ne bo mogla izogniti vprašanjem financiranja učenja in izobraževanja kot dejavnosti, ki poteka vse življenje.

V izobraževanju na visokošolski stopnji je čedalje več udeležencev, ki tudi po andragoški opredelitvi spadajo $\mathrm{v}$ izobraževanje odraslih ali nadaljevalno izobraževanje. ${ }^{9} \mathrm{Z}$ ugodnejšo sistemsko ureditvijo in organiziranostjo visokošolskega izobraževanja odraslih ter $\mathrm{z}$ ustrezno spoznanimi in uveljavljenimi potrebami se bo to začelo dogajati tudi pri nas.

$\mathrm{Za}$ udeleženca tega področja izobraževanja ali študija na visokošolski ravni je treba poiskati ustrezen izraz, ki bo ustrezno označeval status in značilnosti osebe in tudi programa, ki ga zdaj poimenujemo $\mathrm{z}$ anahronističnim, vsekakor pa tudi arhaičnim in slabšalnim izrazom »izredni «. Izraz iz polpreteklega obdobja (izobraževanje ob delu, iz dela itn.) so odslikavali takšno prizadevanje, čeprav so se oblikovalci tedanjega sistema hoteli izogniti 
predvsem nezaželenemu izrazu »izobraževanje odraslih « in poudariti povezanost izobraževanja $\mathrm{z}$ delom. Ker je ustrezne angleške izraze "part-time « in »full-time « težko prevesti v slovenščino, kaže sprejeti izraze, ki opredeljujejo resnični pomen in naravo tega izobraževanja, to pa je "nadaljevalni študij « ali program, »študent nadaljevalnega izobraževanja « ali študija ipd. Seveda kot nasprotje »začetnemu《 študiju ali programu oziroma študentu začetnega izobraževanja ali študija.

\section{IZOBRAŽEVANJE ODRASLIH $\sim$ NAJBOLJ DINAMIČNI NABOI VSEGA DANAŠNJEGA IZOBRAŽEVANJA IN VZGOJE}

Trditev, ki se natančno glasi, da je "andragoški sindrom s teoremom permanentnega izobraževanja najbolj dinamičen naboj za razvijanje današnje teorije vzgoje in izobraževanja « ter pomeni "najbolj podkrepljeno spod-

Pred visokošlskim izobraževanjem so danes śtevilni izzivi, visokošolsko izobraževanje odraslih pa je na kenici tega izziva. Ce to velia za takśne razmere, kot so v razvitih državah (npr. v ZDA, Kanadi, V. Britanifi itn.), poten nora še bolj veljati za po površini in śtevila prebivalstva majhno Slovenijo, saj so njeni razvoi, moŻnosti in uspešnost odločllno odvisni od znanja, poleg rega pa sno hudo obremenjeni z neugodno izobrazbeno sestavo svojega prebivalstva. Neizrabljene izobrazbene zmoglivosti Slovenije (mislimo na populacijo odraslih, ki niso dosegli svojim sposobnostim ustrezne začetne izobrazbe) obsegajo već sto tisoč ljudi.

budo za prenovo smotra, sistema, vsebine in prakse vzgoje in izobraževanja «, je zapisal naš znani pedagog teoretik Franc Pediček. (Andragogika. V: Pedagogika danes. Obzorja, Maribor, 1992, 386).

Tradicionalni koncepti izobraževanja se čedalje bolj umikajo novim. Sistem, ki temelji na razredni organizaciji, semestrih in na zelo omejeni izbiri učnih metod, se temeljito spreminja; če pa se še ni, ga bo treba spremeniti. $\mathrm{Za}$ to spreminjanje ima precej zaslug prav izobraževanje odraslih, saj temu nikakor ne ustreza klasični model šolskega poučevanja in so marsikje prisilili organizatorje in izvajalce izobraževanja, med njimi tudi univerze, $\mathrm{k}$ zunanjim in notranjim organizacijskim spremembam vzgojno-izobraževalnega procesa. Pri tem zasledimo te faze spreminjanja organiziranosti izobraževanja:
1. opuščanje togih prostorskih in časovnih shem izobraževalnega procesa;

2. opuščanje togih in pretiranih administrativnih predpisov pri vstopanju in izstopanju v izobraževanje;

3. opuščanje toge povezanosti izvajanja izobraževanja $\mathrm{z}$ ugotavljanjem in potrjevanjem znanja.

To spodbuja $\mathrm{k}$ novi organiziranosti izvajalcev (ne le šol, tudi drugih); $\mathrm{k}$ drugače (izbirno, gibljivo, kombinirano, interdisciplinarno, medinstitucionalno, projektno, raziskovalno, s povezovanjem verbalnega pridobivanja znanja in izkušenjskega učenja) sestavljenih in sestavljivih programih; $\mathrm{k}$ aktivnemu sodelovanju udeležencev; $k$ inovativni, dinamični organizaciji izobraževalnega procesa, $\mathrm{k}$ iskanju novih poti do znanja (po pravilu, da je pomembno pridobiti znanje, in niso pomembni načini, kako se ga pridobi), vključujoč pri tem organizirane možnosti za ugotavljanje in potrjevanje pridobljenega znanja, neodvisno od izvajalca izobraževanja, vendar v skladu z zahtevanimi standardi in normativi.

Posebno pomembno je za spreminjanje tradicionalnega šolskega kalupa uvajanje metod samostojnega učenja. Tu nam teorija in praksa drugih, zlasti razvitih držav, ponujata že veliko preskušenih možnosti. Zlasti v visokošolskem izobraževanju zadnjih desetletij je postalo samostojno učenje bistvena prvina spreminjanja tradicionalne šolske sheme. Začelo je spodrivati zakoreninjeni avtoritarni slog izobraževanja, ki daje moč in pristojnost za odločanje le enemu - učitelju, in uveljavljati zahtevo po porazdelitvi moči med poglavitna udeleženca vzgojno-izobraževalnega procesa - učitelja in učenca (lahko pa so tudi drugi). Gre za obojestransko in medsebojno odločanje in sporazumevanje, za prerazporeditev moči odločanja pri vseh bistvenih prvinah izobraževalnega procesa ali ciklusa: pri določanju ciljev, načrtovanju, izpeljavi in spremljanju programov ter pri ocenitvi in ovrednotenju učinkov izobraževanja in/ali učenja. Glede na stopnjo nadzora, ki ga imata bodisi učitelj bodisi učenec pri izobraževanju ali učenju, lahko različne mogoče prijeme razvrstimo v kontinuum, ki poteka od popolnega učiteljevega nadzora izobraževalnega ali učnega procesa $z$ vidika učitelja (npr. predavanje) do njegovega popolnega nadzora $z$ vidika učenca (npr. samostojno učenje); vmes 
so zanimive, nekatere novejše, druge pa manj nove možnosti za izobraževanje, kot so programirano učenje, učenje $\mathrm{z}$ računalnikom, študij po dogovoru ali pogodbi, študij z individualnimi učnimi projekti, samostojno učenje v skupini itn.

Zaradi sprememb pri razvoju učne in izobraževalne tehnologije, načina življenja, povečevanja vloge organiziranega samostojnega učenja in učenja $\mathrm{v}$ skupinah $\mathrm{v}$ primerjavi s tradicionalnim poukom - vse to pa so metode in oblike, ki jih je najprej uvedlo izobraževanje odraslih - postaja visoko izobraževanje čedalje bolj področje andragogike in aplikacije spoznanj iz izobraževanja odraslih. Ta disciplina je $\mathrm{v}$ zadnjih desetih letih izjemno napredovala in je $v$ resnici nosilka velikih sprememb $\mathrm{v}$ pojmovanju ter praksi izobraževanja in učenja odraslih, pa tudi pri celotni preobrazbi vzgoje in izobraževanja. Pri nas jo zanesljivo še premalo razvijamo in uporabljamo.

\section{UNIVERZA GIBALO RAZVOIA ZNANIA IN INOVATIVNOSTI IZOBRAŽEVANIA TER UČENIA}

$\mathrm{V}$ naravi univerze - bolj kot $\mathrm{v}$ naravi drugih ustanov za izobraževanje - obstaja dilema, ki izvira iz njenega dvojnega poslanstva: akademskosti ali akademske in znanstvene odličnosti ter univerzalnosti, ki opredeljuje univerzo kot kraj in središče širjenja znanja ter kulture za vse ljudi. Slednje je jasno povedano tudi v poročilu o Unescovi raziskavi, ki jo je vodil Jacques Delors, in je objavljena tudi $\mathrm{v}$ slovenskem prevodu z naslovom Učenje: skriti zaklad (Ministrstvo za šolstvo in šport, Ljubljana, 1996, str. 122-132).

$\mathrm{V}$ primerjavi s tradicionalnim lahko netradicionalno (inovativno) na univerzi štejemo $\mathrm{v}$ zdajšnjih razmerah pri nas prej kot izredno, redko; ob »rednem « se težko uveljavlja. Tudi $\mathrm{v}$ razvitih državah poznajo univerze, ki s tradicionalno organiziranostjo ohranjajo svoj sloves in odličnost; $\mathrm{k}$ temu tipu univerze pogosto spada ohranjanje tradicionalnih metod in pristopov in tudi stroga selektivnost pri pridobivanju udeležencev. Vendar pa je tudi res, da obstajajo univerze, ki so vir inovacij tudi na didaktičnem in metodičnem področju; te pospešujejo uporabo tako imenovanih netradicionalnih pristopov in metod. To niso le univerze, ki se tudi imenujejo odprte (open university), temveč tudi druge. Zanje je značilno, da pogosteje uporabljajo pojme, kot so samostojno učenje, multimedijsko izobraževanje, izobraževanje in učenje na daljavo, učenje po dogovoru, projektno učenje, delavnica ipd. Področje, ki je pri tem najpogostejše, je prav izobraževanje odraslih. Velik razvoj je izobraževanje odraslih doživelo $v$ ZDA prav po zaslugi univerz. Univerze ali visoko šolstvo so glavna središča in gibalo razvoja bolj ali manj vsega izobraževanja odraslih, ne le tistega na univerzah in visokih šolah, in to svojo vlogo s ponosom poudarjajo, se z njo postavljajo. Pri nas pa je povsem drugače. Pri nas je izobraževanje odraslih na univerzi postranska zadeva (margina), še zmeraj bolj »izreden " kot reden pojav. Pogost motiv, da se institucije odločijo za njegovo izvedbo, je pridobitev dodatnega denarja; če ne bi bilo tega, bi bilo izobraževanja odraslih na visokošolskih organizacijah še manj. Univerza in visoko šolstvo pri nas jemljeta izobraževanje odraslih kot nekaj sebi tujega, netipičnega, izrednega.

Spreminjanje populacije študentov seveda ne more ostati brez vpliva na izobraževalno ustanovo, ki je namenjena njim? Ali pomeni

Smo država $z$ velikini razvojnimi želiami in država $v$ prehodnem obdobju. Po mnogih količinskih dejavnikih se Slovenija težko primerja z bogatimi in razvitimi državami. Zato je toliko bolj odvisna od kakovosti storitev v gospodarstru, upravljanju, znanosti, kulturi; $\mathrm{z}$ drugimi besedami, odvisna je od „človeških virov火. Znanje ima vlogo kritičnega dejavnika v razvoju Slovenje. Slovenija bo postala uspešna redaj, ko se bo spremenila v inovacijko družbo, ki se lahko sproti prilagaja sprememban v nednarodnih gospodarskih in političnh razmerih ter tehnoloskin sprenembam.

tako spreminjanje "odzivnost « ali "potrošništvo«? Ali lahko zadovoljimo oziroma naj bi zadovoljili zahteve trga ali pa moramo obdržati neki nespremenljivi "standard izobraževanja».

\section{POTREBE}

Potrebe seveda niso le zadeva posameznikov, temveč prav toliko tudi podjetij in ustanov, ki potrebujejo kadre, izvajalcev, zaposlovalcev in države.

Trenutno smo v Sloveniji še $\mathrm{v}$ nekakšnem negibnem položaju, za katerega je značilno to, da:

\section{A S 10}



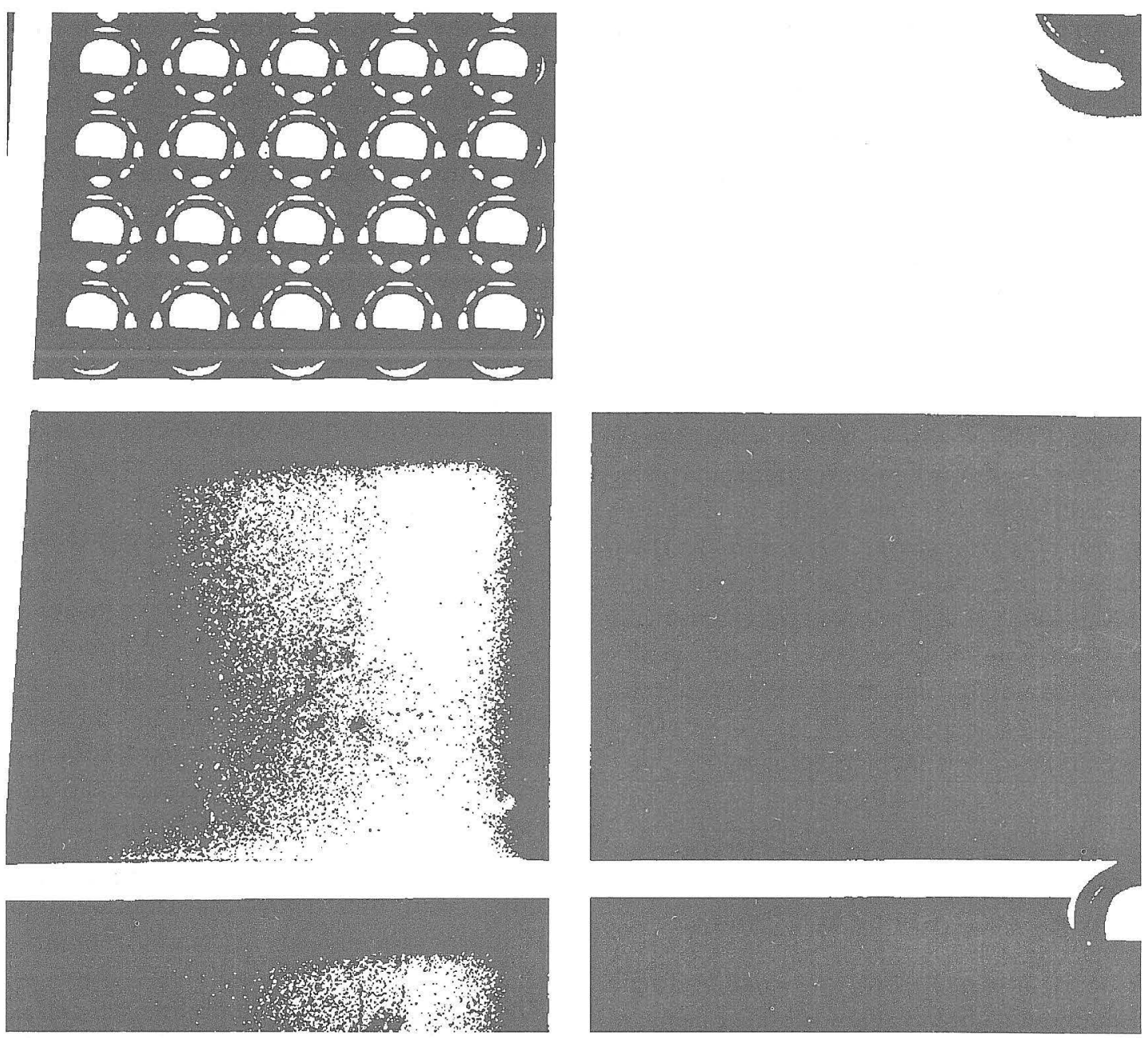

- Izvajalke - visokošolske organizacije le izjemoma ugotavljajo potrebe po izobraževanju študentov nadaljevalnega izobraževanja. Tako je večinoma opredeljen tudi njihov odnos do takšnega študija: ne spodbujajo ga posebej; mu ne prilagajajo svojih programov in organizacije; ne pripravljajo posebne ponudbe zanj in je tudi ne objavljajo v javnosti; za to področje se ne pripravljajo posebej niti strokovno niti organizacijsko, kot da ga ne bi potrebovali ali da po njem ni posebnega povpraševanja.

- Podjetja in ustanove - uporabniki še ne pritiskajo s svojimi zahtevami na izvajalce. Če bi bolj čutili potrebe in usodnost tega, ker jih ne zadovoljujejo, bi bolj pritiskali na izvajalce $\mathrm{z}$ zahtevami, da tako izobraževanje potrebujejo. Še zmeraj si zatiskajo oči in rajši znižujejo raven zahtevane izobrazbe svojih delavcev, kot da bi povečali zahteve.

- Zaposlovalci. Nimajo posebnega vpliva in ne namenjajo posebne pozornosti ustvarjanju možnosti za visokošolsko izobraževanje delavcev, čeprav mnogi med njimi gotovo iščejo zaposlitev.

- In država. Če lahko vzamemo kot merilo za presojo pripravo in uvajanje ustrezne strategije, potem niti $\mathrm{v}$ zvezi $\mathrm{z}$ državo ne moremo govoriti o posebni skrbi in pozornosti za potrebe v izobraževanju odraslih.

\section{STRATEGIJA VSEŽIVLJENISKOSTI UČENIA}

Strategija vseživljenjskosti učenja je nedvomno za celotno visokošolsko izobraževanje, ne le za izobraževanje odraslih, velik izziv. Cas zahteva presojo o ustreznosti tradicionalnega in izzivalnosti netradicionalnega. Je izziv za obrambo pred čedalje večjimi pritiski »učeče se družbe « ali za sprejemanje njenih pobud. Ali jo bo univerza zavračala kot tujek ali pa jo bo začela postopno sprejemati in spoznavati, da je to pridobitev tudi za visokošolsko izobraževanje. Že danes vemo, da bo jutri vsakdo potreboval več izobrazbe.

Sestavljalci poročila in priporočil s Prve svetovne konference o vseživljenjskem učenju, ki je bila decembra 1994 v Rimu (imenovali so 
jo: Akcijski načrt za 21. stoletje), so med priporočili, namenjenimi posebej posameznikom, organizacijam, gospodarstvu in industriji, izobraževalnim organizacijam ter vladam, občilom in sebi kot organizatorjem akcije, zapisali, da bi morale še posebno univerze: - voditi vse izobraževalne dejavnosti, ki vodijo k spremembam;

- šteti celotno skupnost kot vir nekdanjih, zdajšnjih in prihodnjih študentov;

- spodbujati in širiti raziskovanje učenja;

- spodbujati strokovne organizacije, da bodo pospeševale vseživljenjsko učenje med svojimi članicami;

- upoštevati zahteve vseživljenjskosti učenja, ko pridobivajo nove sodelavce in jih uvajajo $\mathrm{v}$ delo;

- uvajati programe, ki omogočajo ugotavljanje in potrjevanje poprejšnjega znanja;

- sodelovati pri uvajanju nove izobraževalne tehnologije, s katero pomagamo tistemu, ki se uči.

Nastal je tudi že pojem: "učeča se univerza " (learning university) kot institucionalizirana oblika in del družine $\mathrm{v}$ "učeči se družbi«.

\section{RAZVOJNO-RAZISKOVALNO SREDIŠČE ZA VISOKOŠOLSKO IZOBRAŽEVANJE ODRASLIH}

Iz povedanega je mogoče ugotoviti, da je visokošolsko nadaljevalno izobraževanje pri nas $\mathrm{v}$ vseh pogledih pastorek. Ne moremo pa se več dolgo slepiti s tem, da bodo potrebe po takšnem izobraževanju še naprej tako skrite in neaktualizirane, kot so zdaj. Tudi uporabniki se bodo zdramili in začeli zahtevati. Takšno spremembo je začasno še mogoče rešiti z improvizacijami, zadovoljevanjem potreb brez ustrezne kakovosti. A dolgo to ne bo zdržalo. Tedaj se bodo izvajalci znašli v težavah.

Visokošolsko izobraževanje tudi pri nas potrebuje ustrezno razvojno-raziskovalno središče za snovanje ustreznih rešitev, ugotavljanje in spremljanje stanja, uvajanje novih oblik in metod, pripravo strategij in sistemskih rešitev, stalne in temeljite evalvacije stanja in strokovno pripravo potrebnih ukrepov. V njem bo moralo imeti pomembno mesto tudi visokošolsko izobraževanje odraslih, delo pa mora temeljiti na koncepciji in strategiji vseživljenjskosti učenja ter izobraževanja.

V preteklosti je bil temu najbliže Center za razvoj Univerze, ki pod takšnim imenom in s takšno usmeritvijo več ne deluje.

1 Schmidt, Vlado: Znanstveno-tebnična revolucija, šola in vzgoja. Terorija in praksa, 1971, letnik 8, 5, 716.

2 Objavljeno kot raziskovalno poročilo $z$ naslovom Visokošolsko izobraževanje odraslih (B. Mihevc idr.), RP Izobraževanje odraslih kot dejavnik razvoja Slovenije, Andragoški center Slovenije, Ljubljana 1994 (Raziskovalno poročilo 4) ter $v$ publikaciji $z$ istim naslovom, $A n$ dragoški center Slovenije, Ljubljana, 1995 (Zbirka ätudije in raziskave 4).

${ }^{3}$ Visoko šolstvo. V: Bela knjiga o vzgoji in izobraževanju $v$ Sloveniji. Ministrstvo za šolstvo in šport, Ljubljana, 1995, 259-292.

Razvoj izobraževanja odraslih, V: $n$. d., 293-336.

${ }^{4} \mathrm{~V}$ Beli Knjigi je zapisano, da sta gradivo pripravila $d r$. Ivan Svetlik in dr. Pavle Zgaga.

${ }_{5}$ Poglavie so pripravili: Olga Drofenik, mag. Angelca Ivančič, dr. Zoran Jelenc, Sonja Klemenčič, mag. Jože Miklavc, mag. Ester Možina, Nataša Elvira Jelenc in Maša Stavanja.

${ }^{6}$ P. K. Cross: Adults as Learners. Increasing Participation and Facilitating Learning. Jossey Bass Publishers, S. Francisco, 1981.

7 Zakon o visokem šolstvu. Ur. list RS, 37. člen, 1993, $67,3304$.

8 Študentje na visokošolski ravni so po številnih merilih odraslosti v resnici odrasli: so fizično, psibično, pravno in $v$ marsičem tudi socialno zrele ali odrasle osebe.

${ }^{9} \mathrm{~V}$ uvodu h knjižni izdaji ugotovitev iz raziskave Visokošolsko izobraževanje odraslih, ACS, 1994, str. 19, smo navedli podatke ameriške andragoginje P. K. Cross, ki je že leta 1981 opozarjala, da se delež študentov "part-time" izenačuje s številom tistih, ki se udeležujejo študija kot študentje "full-time«. 